Graphical Abstract

Optically active aziridine esters by nucleophilic addition of nitrogen heterocycles to a chiral $2 \mathrm{H}$-azirine-2-carboxylic ester

M. José Alves*, A. Gil Fortes, Luis F. Gonçalves Departamento de Química, Universidade do Minho, Campus de Gualtar, 4710-057, Braga, Portugal

Chirally enriched ethyl 3-methyl-2H-azirine-2-carboxylate acts as an efficient alkylating agent for a variety of five membered aromatic nitrogen heterocycles. 


\title{
Optically active aziridine esters by nucleophilic addition of nitrogen heterocycles to a chiral $2 \mathrm{H}$-azirine-2-carboxylic ester
}

\author{
M. José Alves , A. Gil Fortes, Luis F. Gonçalves \\ Departamento de Química , Universidade do Minho, Campus de Gualtar 4710-057 Braga, Portugal
}

Abstract - Chiral enriched ethyl 3-methyl-2H-azirine-2-carboxylate acts as an efficient alkylating agent for a variety of five membered aromatic nitrogen heterocycles.

Keywords: chiral $2 \mathrm{H}$-azirines; nucleophilic additions; diastereoselectivity; aziridines.

We have previously found that $2 H$-azirine-3-carboxylic esters $\mathbf{1}$ and $\mathbf{2}$ are useful precursors for functionalized aziridines $\mathbf{3}$ that are formed by simple nucleophilic addition to the respective $2 \mathrm{H}$-azirine. Reactions are stereoselective, the addition being on the less hindered face of the azirine to form the trans products $\mathbf{3}$ (scheme 1). ${ }^{\mathbf{1}}$ The main drawback to this methodology as a route to $\alpha$-amino esters $\mathbf{3}$ is that there is currently no method of obtaining the $2 \mathrm{H}$-azirine-3-carboxylic ester $\mathbf{1}$ in an enantiopure form. As a first approach to a chiral aziridine, the azirine 2 bearing the ( $N, N$-diethylsulfamoyl) isobornyl unit as the chiral auxiliary in the ester moiety, was obtained ${ }^{2}$ and reacted with nucleophiles. The expected addition reactions took place, but diastereodifferentiation of the two faces of the azirine was generally not good. ${ }^{2}$ So, we concluded that it would be difficult to generate chiral adducts if the chirality of the compound is outside the ring. On the other hand, $2 \mathrm{H}$ azirine-2-carboxylic esters of type $\mathbf{4}$ can be accessed in optically active form from ester aziridines 5 by Swern oxidation ${ }^{3}$ (scheme 2 ) or from $\beta$-ketoester oxime $p$-toluenesulfonates 6, by a modified Neber elimination, using $(+)$-dihydroquinidine as a chiral tertiary base (scheme 3). ${ }^{4}$ To our surprise we find that 2-alkoxycarbonylazirine compounds are electrophilic enough to react with nitrogen heterocycles at room temperature within some hours, showing a close relationship with the electrophilicity of $2 \mathrm{H}$-azirine-3-carboxylic esters, despite their lower degree of activation. The reason why this behaviour was not expected is associated with lack of conjugation of the $\mathrm{C}=\mathrm{N}$ bond with the carbonyl group in compounds 4.

\footnotetext{
* Corresponding author. Tel.: +00-351-253604376; fax: +00-351-253-678983; e-mail: mja@quimica.uminho.pt.
} 
The chirally enriched $2 \mathrm{H}$-azirine-2-carboxylic esters firstly reported by Zwanenburg and coworkers ${ }^{4}$ were used as electrophiles in addition reactions to five and five fused aromatic nitrogen heterocycles. The azirine was obtained by stirring a solution of $6\left(R^{1}=M e, R^{2}=E t\right)$ in dry toluene in presence of (+)-dihydroquinidine (1 equiv.), which was removed in the end of the reaction by extraction with aq. citric acid (10\%); the crude product was used without further purification. The ${ }^{1} \mathrm{H}$ NMR spectrum of the reaction mixture in the presence of ytterbium chiral shift reagent $(\mathrm{Yb}(\mathrm{tfc})$ ) (ee 70\%) is in good agreement with the enantiomeric excess reported. ${ }^{4}$ Aziridines 8 are formed by stirring a solution of the azirine $\mathbf{7}$ with the nucleophile in acetonitrile at room temperature and in presence of $\mathrm{Na}_{2} \mathrm{CO}_{3}$. Adducts are generally stable enough to be isolated after flash chromatography. The only exceptions are the adducts $\mathbf{8 d}$ and $\mathbf{8 i}$. The indole adduct $\mathbf{8 d}$, proved to be a single compound in the crude mixture by ${ }^{1} \mathrm{H}$ NMR analysis, although it reacts on silica during dry-flash chromatography, reverting back to azirine 7 and indole that were recovered in $80 \%$ and 50\% yields respectively. 7-Azaindole adduct $\mathbf{8 i}$, also reacts on silica, giving back the azaindole (78\%) and a dimer of the azirine, compound $\mathbf{1 0}$ obtained in 65\% yield. The nitrogen heteroaromatic eliminations of the aziridine adducts have been described before from aziridine adducts 9 .

Also the pyrazine of type $\mathbf{1 0}$ was observed before by decomposition of aziridine adducts $\mathbf{9}$ in the presence of acid (silica) or base. Reaction of the azirine 7 with purine, gave a mixture of N-7 (8g) and N-9 (8f) alkyl isomers in 1:2 ratio respectively, in agreement with the higher nucleophilicity of N-7 and N-9 compared with N-1 and N-3 in purine. ${ }^{\mathbf{5}}$ The adducts were fully separated by dry flash chromatography. Addition products were isolated as oils $(\mathbf{8 b}, \mathbf{8 c}$, $\mathbf{8 g}, \mathbf{8 h}$ ) or solids (8a, 8e, 8f) in $60-80 \%$ yield. ${ }^{1} \mathrm{HNMR},{ }^{13} \mathrm{C}$ NMR and high resolution mass spectra of these compounds fit the proposed structures. The main features of the NMR spectra of the addition products are the $\mathrm{NH}$ doublet in a narrow region $\delta_{\mathrm{H}} 1.82-2.12 \mathrm{ppm}$ that couples with the neighbouring $\mathrm{CH}$ at $\delta_{\mathrm{H}}$ 2.85-3.05. The coupling constant between them is of the order of 8.7 to $9 \mathrm{~Hz}$ (see table 1). A very similar interaction was described in other aziridines of type $\mathbf{8},{ }^{\mathbf{1 , 2}}$ e.g. aziridine $\mathbf{9}$ for the $\mathrm{NH}-\mathrm{CH}$ moiety. ${ }^{13} \mathrm{C}$ spectra are also indicative, in all cases consistently showing two $\mathrm{sp}^{3}$ carbons at $\delta_{\mathrm{C}} 42-43 \mathrm{ppm}$ and $62 \mathrm{ppm}$, assigned to C-2 and C-3, respectively. ${ }^{6}$

According to NOe experiment on compound $\mathbf{8 f}$ and $\mathbf{8 g}$, the stereochemistry of addition seems to be anti to the ethoxycarbonyl group of the azirine. Irradiating $\mathrm{H}-2$ (d) of the aziridine moiety at $2.9 \mathrm{ppm}$ showed an enhancement (3.72\%) of the purine signal H-8 at $8.34 \mathrm{ppm}$. On the other hand, irradiation of H-2 (d) of the other isomer at $2.97 \mathrm{ppm}$ gave an enhancement of 
H-8 at 8.48 ppm (2.72\%) and H-6 at 9.15 ppm (2.86\%). Free rotation around C-N bond between the aziridine and purine tied moieties would explain the NOe of the aziridine $\mathrm{H}-2$ over the purine $\mathrm{H}-8$ and $\mathrm{H}-6$ in isomer $\mathbf{8 g}$, and $\mathrm{H}-2$ of the aziridine over the purine $\mathrm{H}-8$ in isomer 8f. The anti azirine addition was observed before in $2 H$-azirine-2-carboxylates, ${ }^{7}$ although in the case of Grignard ragents, syn addition has been reported instead. ${ }^{\mathbf{3 , 6}}$

The ee of the products was established by further functionalisation of the $\mathrm{NH}$ in compound 8d with a chiral acylating agent ((1S)-(+)-camphorsulfonyl chloride). A mixture of two major diastereomers was obtained in a ratio between $4: 1$ to $5: 1$, which is approximately the same enantiomeric ratio observed in the starting chiral azirine. Two other minor diastereomers were also detected in a ratio about $4: 1$, due to the syn addition of indole to the azirine. The two major diastereomers represent $85 \%$ of the crude mixture, which indicates a good diastereoselectivity for the addition reaction.

The obvious extension of this work to carbon and sulfur nucleophiles did not give promising results. Reaction of $\mathbf{7}$ with phenylmagnesium bromide produced a 3:1 mixture of diastereomers, indicating that the addition is not stereoselective in this case. Careful studies of the reaction over a temperature range of $-78{ }^{\circ} \mathrm{C}$ to $-20{ }^{\circ} \mathrm{C}$ always gave products in the same isomeric ratio. On the other hand, 4-chlorothiophenol reacted in an undefined way and it was not possible to reproduce a clear procedure for the reaction. This was ascribed by us to be the result of easy addition/elimination of the sulfur nucleophile.

In conclusion, we found the relative non-activated azirine 7 to be a good alkylating agent for nitrogen heterocycles, opening the possibility of forming chiral aziridines of type $\mathbf{8}$ with excellent diastereoselectivity.

\section{Acknowledgements}

We thank Dr Thomas L. Gilchrist for helpful discussions of the work and Fundação Ciência e Tecnologia for project funding (POCTI /32723/QUI/2000).

\section{References}

1.Alves, M.J.; Ferreira, P.M.T.; Maia, H.L.S.; Monteiro, L.S.; Gilchrist, T.L., Tetrahedron Lett., 2000, 41, 4991-4995.

2.Álvares, Y.S.P.; Alves, M.J.; Azoia, N.G.; Bickley, J.F. Gilchrist, T.L., J. Chem. Soc., Perkin Trans 1, 2002, 1911-1919.

3.Davis, F.A.; Deng, J.; Zhang, Y.; Haltiwange, R.C., Tetrahedron, 2002, 7135-7143.

4.Verstapen, M.M.H.; Ariaans, G.J.A.; Zwanenburg, B., J. Am. Chem. Soc., 1996, 118, 84918492.

5.Shaw, G.; In Comprehensive Hetrocyclic Chemistry; Katritzky, A. R., Rees, C. W. Eds.; Pergamon Press: New York, 1984; Vol. 5, Chap. 4, pp 499-605. 
6.Davis, F.A.; Liang, C-H.; Lin, H.J., J. Org. Chem, 62, 1997, 3796.

7.Carlson, R.M.; Lee, S.Y., Tetrahedron. Lett., 1969, 4001.

Table 1. Some physical and spectroscopic characteristics for aziridines $\mathbf{8}$.

\begin{tabular}{|c|c|c|c|c|c|c|}
\hline \multirow[t]{2}{*}{$\mathbf{N}^{\circ}$} & \multirow{2}{*}{$\begin{array}{l}\text { Yield } \\
(\%)\end{array}$} & \multirow{2}{*}{$\begin{array}{l}\text { m.p. } \\
\left({ }^{\circ} \mathrm{C}\right)\end{array}$} & \multirow{2}{*}{$\underset{\left(\mathrm{CHCl}_{3}\right)}{[\alpha]_{\mathrm{D}}{ }^{20}}$} & \multirow[t]{2}{*}{${ }^{1} \mathrm{H}$ NMR $\left(\mathrm{CDCl}_{3}\right)$} & \multicolumn{2}{|c|}{${ }^{13} \mathrm{C} \mathrm{NMR}\left(\mathrm{CDCl}_{3}\right)$} \\
\hline & & & & & C-2 & C-3 \\
\hline 8a & 60 & $\begin{array}{l}>70 \text { (dec.) } \\
\text { (EtOAc: Pet. } \\
\text { ether 40-60) }\end{array}$ & -36 & $\begin{array}{l}1.96 \text { (bd, 1H, N-H, J8.7Hz) } \\
2.95 \text { (d, 1H, C-H, J8.7Hz) }\end{array}$ & 42.62 & 62.44 \\
\hline $\mathbf{8 b}$ & 83 & oil & -91 & $\begin{array}{l}1.97 \text { (bs, } 1 \mathrm{H}, \mathrm{N}-\mathrm{H}) \\
2.86(\mathrm{~d}, 1 \mathrm{H}, \mathrm{C}-\mathrm{H}, J 8.7 \mathrm{~Hz})\end{array}$ & 42.63 & 62.37 \\
\hline $8 c$ & 59 & oil & -83 & $\begin{array}{l}1.86(\mathrm{~b}, 1 \mathrm{H}, \mathrm{N}-\mathrm{H}) \\
2.79(\mathrm{~d}, 1 \mathrm{H}, \mathrm{C}-\mathrm{H}, J 9.0 \mathrm{~Hz})\end{array}$ & 42.83 & 62.32 \\
\hline 8d & --- & --- & --- & $\begin{array}{l}1.85 \text { (bd, } 1 \mathrm{H}, \mathrm{N}-\mathrm{H}, J 9.0 \mathrm{~Hz}) \\
\mathbf{b}) \\
3.04(\mathrm{~d}, 1 \mathrm{H}, \mathrm{C}-\mathrm{H}, J 9.0 \mathrm{~Hz})\end{array}$ & --- & --- \\
\hline $8 e$ & 60 & $\begin{array}{l}>65 \text { (dec.) } \\
\text { (Et }{ }_{2} \mathrm{O} \text { : Pet. } \\
\text { ether } 40-60 \text { ) }\end{array}$ & -22 & $\begin{array}{l}1.82 \text { (bs, } 1 \mathrm{H}, \mathrm{N}-\mathrm{H}) \\
2.85 \text { (bs, } 1 \mathrm{H}, \mathrm{C}-\mathrm{H})\end{array}$ & 43.16 & 62.20 \\
\hline $8 f$ & $\begin{array}{c}41 \\
\text { (major) }\end{array}$ & $\begin{array}{l}90-92 \\
\text { (EtOAc) }\end{array}$ & -53 & $\begin{array}{l}1.99(\mathrm{~d}, 1 \mathrm{H}, \mathrm{N}-\mathrm{H}, J 9.0 \mathrm{~Hz}) \\
2.94(\mathrm{~d}, 1 \mathrm{H}, \mathrm{C}-\mathrm{H}, J 9.0 \mathrm{~Hz})\end{array}$ & 41.93 & 62.69 \\
\hline $8 g$ & $\begin{array}{c}27 \\
\text { (minor) }\end{array}$ & oil & -47 & $\begin{array}{l}2.12(\mathrm{~d}, 1 \mathrm{H}, \mathrm{N}-\mathrm{H}, J 8.7 \mathrm{~Hz}) \\
2.96(\mathrm{~d}, 1 \mathrm{H}, \mathrm{C}-\mathrm{H}, J 8.7 \mathrm{~Hz})\end{array}$ & 42.72 & 62.63 \\
\hline $8 h$ & 62 & oil & -67 & $\begin{array}{l}1.88(\mathrm{~d}, 1 \mathrm{H}, \mathrm{N}-\mathrm{H}, J 9.0 \mathrm{~Hz}) \\
2.89(\mathrm{~d}, 1 \mathrm{H}, \mathrm{C}-\mathrm{H}, J 9.0 \mathrm{~Hz})\end{array}$ & 42.76 & 62.38 \\
\hline $8 \mathbf{i}$ & --- & --- & --- & $\begin{array}{l}1.85(\mathrm{~d}, 1 \mathrm{H}, \mathrm{N}-\mathrm{H}, J 9.0 \mathrm{~Hz}) \\
2.97(\mathrm{~d}, 1 \mathrm{H}, \mathrm{C}-\mathrm{H}, J 9.0 \mathrm{~Hz})\end{array}$ & --- & --- \\
\hline
\end{tabular}

${ }^{\text {a }}$ Crude material ca $100 \%$ yield. Decomposition after flash chromatography.

b Further characterization was made through the camphor sulfamoyl chloride derivative; the crude material displayed four doublets due to one of the methylenic sulfamoyl protons at 5.29, 5.23, 5.11 and 5.02 in a ratio 1:0.26:0.16:0.06. 

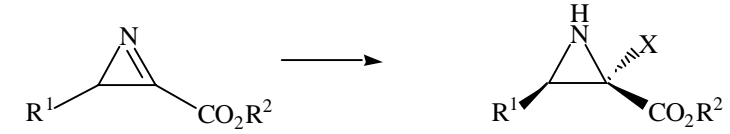

1- $\mathrm{R}^{1}=$ 2,6-dichlorophenyl; $\mathrm{R}^{2}=\mathrm{Me}$

2- $\mathrm{R}^{1}=\mathrm{H} ; \mathrm{R}^{2}=\left(N, N\right.$-diethylsulfamoyl)isobornyl $\quad 3-\mathrm{X}=\mathrm{SAr}, \mathrm{NR}_{2}$

\section{Scheme 1}

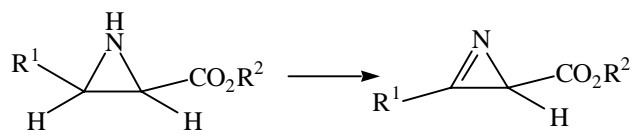

5

4

$\mathrm{R}^{1}=$ alkyl, phenyl

$\mathrm{R}^{2}=\mathrm{Me}$

Scheme 2

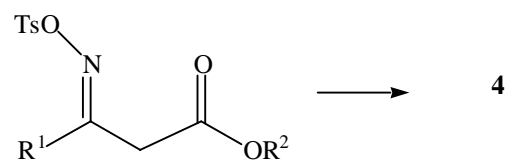

$\mathrm{R}^{1}, \mathrm{R}^{\mathbf{6}}=$ alkyl

Scheme 3

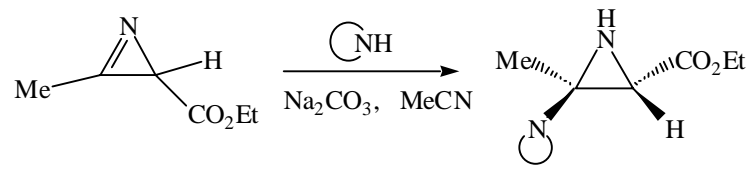

8

$\mathrm{N}-\mathrm{Het}=$<smiles>Cn1cnc2ccccc21</smiles>

8a<smiles>Cn1ccc2ccccc21</smiles>

8d<smiles>Cn1cnc2ncncc21</smiles>

$8 \mathrm{~g}$<smiles>O=[W]n1cncn1</smiles>

8b<smiles>Cn1cccc1C=O</smiles>

$8 \mathrm{e}$<smiles>Cn1cccn1</smiles>

$8 h$<smiles>Cn1ccnc1</smiles>

8c<smiles>Cn1cnc2cncnc21</smiles>

$8 f$<smiles>Cn1ccc2cccnc21</smiles>

$8 \mathbf{i}$

Scheme 4 

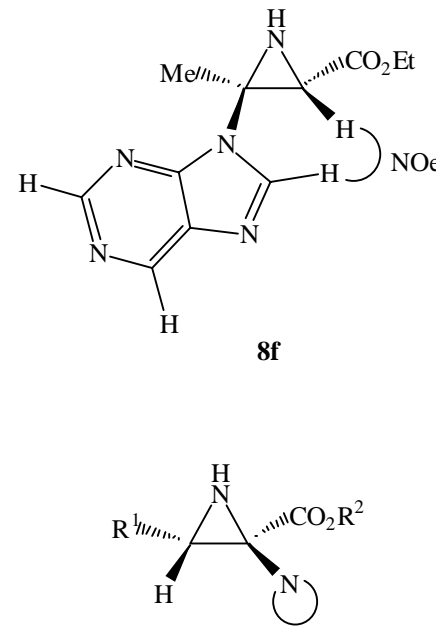

$\mathrm{R}^{1}=\mathrm{H} ; \mathrm{R}^{2}=(N, N$-diethylsulfamoyl)isobornyl

9

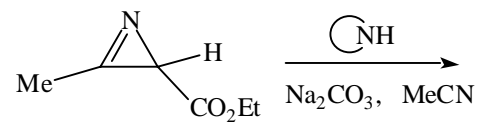

7
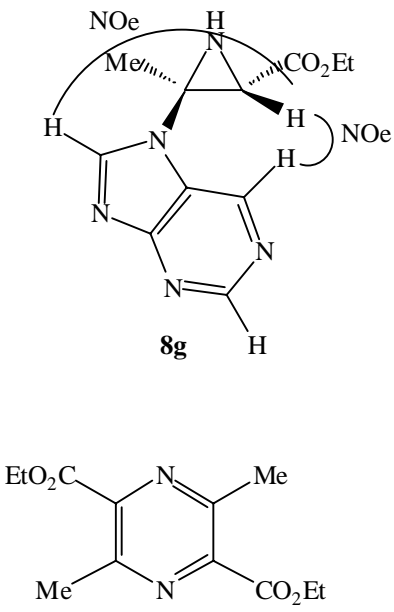

10

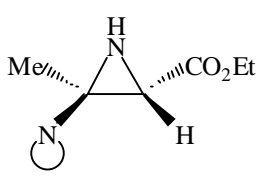

8 